\title{
Evaluation of Microbial Systems for Biotreatment of Textile Waste Effluents in Nigeria: Biodecolourization and Biodegradation of textile Dye
}

\author{
*SAMUEL E. AGARRY; AYOBAMI O. AJANI \\ Biochemical Engineering Research Laboratory, Department of Chemical Engineering, \\ Ladoke Akintola University of Technology, Ogbomoso, Nigeria \\ Tel: +2348055529705 ,
}

\begin{abstract}
The evaluation of some microbial species for the decolourization and degradation of textile dye has been investigated. Six microbial strains were isolated from soil contaminated with textile waste effluents using the spread plate technique and the isolates were identified as bacterial isolates (Pseudomonas fluorescence, Pseudomonas nigificans, and Pseudomonas gellucidium) and fungal isolates (Aspergillus niger, Proteus morganii and Fusarium compacticum \} based on gram staining, morphological and biochemical tests. They were evaluated for their capability to remove colour and degrade dye, reduce chemical oxygen demand (COD) and biological oxygen demand (BOD) levels of textile waste effluents. The results revealed that all the bacterial and fungal isolates have a good potential to remove colour and degrade dye, reduce the COD and BOD levels of the textile waste effluents with percent colour removal, COD and BOD reductions between 39 and $48 \%, 74$ and $97 \%$ and 77 and $95 \%$, respectively. Binary mixed culture of Pseudomonas fluorescence and Aspergillus niger was efficiently utilized for the removal of different initial concentration $(10,15,20,25$ and $30 \mathrm{mg} / \mathrm{l})$ of dye from textile waste effluents. It had a higher percent decolourization than individual isolates. The stirred tank bioreactor was found to be very effective for efficient biotreatment of textile waste effluents. @ JASEM
\end{abstract}

Textile waste effluents contain several types of chemicals such as dyes, dispersants, leveling agents, acids and alkali (Cooper, 1995; Olukanni et al., 2006) that are discharged into water bodies by textile industries without any effective treatment. This increases the chemical oxygen demand (COD) and biochemical oxygen demand (BOD), alters the $\mathrm{pH}$ and gives the water bodies (rivers) intense colourations. Coloured wastewater from textile industries is rated as the most polluted in almost all industrial sectors (Andleeb et al., 2010). Tremendous amount of dyes in textile sectors are continuously being exhausted in wastewater streams due to their poor adsorb ability to the fiber (Wagner, 1993; McMullan et al., 2001). The presence of very small amounts of dyes in water is highly visible and affects the aesthetic merit, water transparency and gas solubility in lakes, rivers and other water bodies (McKay, 1979) and degradation products of these dyes are often carcinogenic (Kim et al., 2003). The treatment of textile waste effluents is still a major environmental concern because of synthetic dyes which are difficult to be removed by conventional physical and chemical technologies (Zhang et al., 2004) such as membrane filtration, coagulation, precipitation, flotation, adsorption, ion exchange, chemical reduction, ultrasonic mineralization, electrolysis and advanced chemical oxidation (Gogate and Pandit, 2004; Kang et al., 2010). Some of these methods are effective but have inherent drawbacks such as high cost, intensive energy requirements, formation of hazardous by-products and generation of sludge which causes secondary pollution (Do et al., 2002; Verma et al., 2003; Maier et al., 2004; Ramya et al., 2007; Dayaram and Dasgupta, 2008). Current available treatment technologies have been reviewed by Robinson (Robinson et al., 2001) and specific attention is given to biological treatment processes because they are cost- effective and environmentally friendly.

The most widely studied class of microorganisms in regard to dye degradation and decolourization are the fungi (Bochart and Libra, 2001; Maxima and CostaFerreira, 2004; Mechichi et al., 2006; Singh et al., 2007; Revankar and Lele, 2007; Ramya et al., 2007, Dayaram and Dasgupta, 2008; Andleeb et al., 2010). A great number of these fungi (especially white-rot fungi) have been shown to excrete extracellular enzymes like lignin peroxidase, manganese peroxidase and laccase (Hatakka, 1994) which catalyze the formation of activated oxygen so that the process of attack on the stable structure of dyes can be initiated. The role of some bacterial and algal species for the decolourization and degradation of textile dyes has also been reported (Jumarkar et al., 2006; Olukanni et al., 2006; Pourbabaee et al., 2006; Togo et al., 2008; Cheriaa et al., 2009). Dyes are removed by biosorption (Fu and Viraraghavan, 2000) and enzymatic mineralization (degradation) by lignin peroxidase, manganese peroxidase, manganese independent peroxidase and laccases (Raaghukumar et al., 1996; Duran et al., 2002; Wesenberg et al., 2003; Svobodova et al., 2006). 
The development of efficient dye degradation and decolourization require a suitable strain and its use under favourable conditions to realize the degradation potential. Therefore, it is important to explore the possibilities of isolating efficient aerobic degraders for use in decolourization and degradation of textile dye waste effluents.

The objective of this study was to isolate microorganisms from soil contaminated with textile dye waste effluents and evaluates their remediation potential to decolourize and degrade dye or reduce the COD and BOD of textile waste effluents. The study is aimed at discovering isolates with efficient biodecolourization and biodegradation potential for use in the biotreatment of textile waste effluents.

\section{MATERIALS AND METHODS}

Microorganisms: The microorganisms used in this study were isolated from soil contaminated with textile waste effluents discharged from one of the textile industry located at Oshodi in Lagos, Nigeria.

Textile waste effluents: The textile waste effluents sample used for this study was obtained from the same textile industry located at Oshodi in Lagos, Nigeria.

Characterization of textile waste effluents: The textile waste effluents was analyzed in triplicates for $\mathrm{pH}$, chemical oxygen demand (COD), biochemical oxygen demand (BOD), total solids (TS), total suspended solids (TSS), total dissolved solids (TDS), chlorides and dye using standard methods (APHAAWWA, 1985).

Determination of $\mathrm{pH}: \mathrm{pH}$ of the samples was determined using $\mathrm{pH}$ meter which has been initially standardized by using buffer solutions of known value before analysis

Determination of Total Solids: A clean dish was taken and dried at $103-105^{\circ} \mathrm{C}$ in an oven to a constant weight (W1). Twenty-five millilitre of thoroughly mixed effluent sample was accurately pipette into a dish, weighed and evaporated to dryness on a steam bath. The residue was dried in an oven for about $1 \mathrm{~h}$ at $103-105^{\circ} \mathrm{C}$ and re-weighed after cooling to room temperature. The cooling was done until the weight of the dish plus residue was constant (W2). The weight of the dish was subtracted to obtain the weight of the total solids.
Determination of Total Suspended Solids: Twentyfive millilitres of the effluent sample was withdrawn into a conical flask with a pipette. It was filtered in Gooch funnel fitted with glass fibre filter paper which has been pre-dried at $103-105^{\circ} \mathrm{C}$. The glass fibre was carefully removed from the Gooch and dried to a constant weight at $103-105^{\circ} \mathrm{C}$ and the weight subtracted from the weight of the filter paper to obtain the weight of the suspended solids.

Determination of Total Dissolved Solids: Total dissolved solid was obtained by the difference between total solids and suspended solids.

Determination of Chlorides: The Chloride was determined by Mohr's titration. Twenty millilitres of sample was placed in a conical flask and $\mathrm{pH}$ adjusted to between 6 and 8 with small amount of $(0.1 \mathrm{M})$ calcium carbonate solution. One millilitre of potassium chromate solution prepared by dissolving $50 \mathrm{~g}$ of potassium chromate in a minimum of distilled water was added and the solution was titrated with $(0.0141 \mathrm{M})$ silver nitrate solution with constant stirring.

Determination of Total dye: Textile sample effluents $(50 \mathrm{mg} / \mathrm{L})$ were taken and their light absorbance was measured at wavelengths of $400-700 \mathrm{~nm}$. UVVIS spectra were determined on a Spectronic Helios alpha spectrophotometer operated with VISION32, and 1 $\mathrm{cm} \times 1 \mathrm{~cm}$ quartz cuvettes (Starna) were used as sample cells.

The values of the various parameters for the untreated textile waste effluents are presented in Table 1.

Table 1: Characterization of the untreated textile waste effluents
\begin{tabular}{|l|l|}
\hline Parameter & $\begin{array}{l}\text { Concentration } \\
(\mathrm{mg} / \mathrm{L})\end{array}$ \\
\hline $\mathrm{pH}$ & $10^{\mathrm{a}} \pm 1$ \\
Biological oxygen demand & $5200 \pm 100$ \\
(BOD) & $6410 \pm 230$ \\
Chemical oxygen demand & $2820 \pm 110$ \\
(COD) & $4560 \pm 160$ \\
Total suspended solids (TSS) & $7380 \pm 270$ \\
Total dissolved solids (TDS) & $916 \pm 25$ \\
Total solids (TS) & $30 \pm 4$ \\
Chlorides & \\
Total dye & \\
$\mathrm{a}=$ no unit for pH
\end{tabular}

Isolation and characterization of microorganisms: The contaminated soil sample $(10 \mathrm{~g})$ was diluted serially $\left(10^{-1}\right.$ to $\left.10^{-7}\right)$. One mililitre from dilution $10^{-2}$ 
and $10^{-3}$ were plated in triplicate on sterile potato dextrose agar plates while dilutions of $10^{-4}, 10^{-5}$ and $10^{-7}$ were plated in triplicates on sterile nutrient agar plates using the pour plate method. Incubations were carried out at room temperature for the potato dextrose agar plates for 7 days and $24 \mathrm{~h}$ for the nutrient agar plates, respectively. Plates yielding 30 to 300 colonies were enumerated for bacterial isolates. Plates with fungal colonies were also enumerated. The colonies of bacteria and fungi were picked randomly using a sterile inoculating loop and sub cultured (to purify) by streaking on nutrient agar plates and potato dextrose agar plates, respectively. The plates were incubated at room temperature for 24 $\mathrm{h}$ (bacterial isolates) and $72 \mathrm{~h}$ (fungal isolates), respectively, to obtain pure colonies. The isolates were identified by gram staining, morphological and biochemical tests using the taxonomic scheme of Bergey's Manual of Determinative Bacteriology (Holt et al., 1994).

Preparation of bacterial and fungal inoculums: In order to meet the nutritional requirement of the microorganisms for proper growth, the textile waste effluents was supplemented with mineral salts medium containing the following compositions $\mathrm{g} / \mathrm{L}$ : glucose $1 \mathrm{~g} ; \mathrm{KH}_{2} \mathrm{PO}_{4} 2 \mathrm{~g} ; \mathrm{K}_{2} \mathrm{HPO}_{4} 7 \mathrm{~g} ; \mathrm{MnSO}_{4} 0.1 \mathrm{~g}$; $\mathrm{Na}_{3} \mathrm{C}_{6} \mathrm{H}_{5} \mathrm{O}_{7} 0.5 \mathrm{~g}$; $\left(\mathrm{NH}_{4}\right)_{2} \mathrm{SO}_{4} 1.0 \mathrm{~g}$ (Ramya et al., 2007). All chemicals were of analytical grade. Colonies were transferred from the agar plates containing the isolates to $100 \mathrm{ml}$ medium (containing both the mineral salt medium and the waste effluent samples in ratio 4:1) in $250 \mathrm{ml}$ Erlenmeyer conical flasks. The flasks were incubated on New Brunswick gyratory shaker (G25-R model, New Jersey, USA) at $120 \mathrm{rpm}$ and $30^{\circ} \mathrm{C}$ for $24 \mathrm{~h}$. The $\mathrm{pH}$ of the medium was adjusted to 7 using $0.1 \mathrm{M} \mathrm{HCl}$ and $0.1 \mathrm{M} \mathrm{NaOH}$. Between $5-10 \%(\mathrm{v} / \mathrm{v})$ of these grown bacterial cultures were used to inoculate fresh flasks and were cultivated at the same conditions for $24 \mathrm{~h}$.

Mycelium and spore suspension of fungal cultures was prepared. Disc of $0.5 \mathrm{~mm}$ containing mycelium and spores $(0.4 \mathrm{mg}$ dry weight) were removed from the borders of fungal colonies on the potato dextrose agar plate and added to $100 \mathrm{ml}$ of medium (containing both the mineral salt medium and the waste effluent samples in ratio 4:1) in $250 \mathrm{ml}$ Erlenmeyer conical flasks. Streptomycin $(0.05 \%)$ was used as antibacterial agent. The flasks were incubated on New Brunswick gyratory shaker (G25-R model, New Jersey, USA) at $120 \mathrm{rpm}$ and $30^{\circ} \mathrm{C}$ for $72 \mathrm{~h}$. The $\mathrm{pH}$ of the medium was adjusted to 6 using $0.1 \mathrm{M} \mathrm{HCl}$ and $0.1 \mathrm{M} \mathrm{NaOH}$. Between $5-10 \%(\mathrm{v} / \mathrm{v})$ of these grown fungal cultures were used to inoculate fresh flasks and were cultivated at the same conditions for $72 \mathrm{~h}$.

Batch microbial treatment studies: Different biodegradation runs were carried out on a $7.5 \mathrm{~L}$ capacity New Brunswick Microferm Twin Fermentor designed for mass cultivation of microorganisms in batch and continuous culture fermentation. The reactor is equipped with a control panel which permits the regulation of agitation and temperature. An autoclaved mineral salt medium $(0.8 \mathrm{~L})$ was measured into the bioreactor and $3 \mathrm{~L}$ of textile waste effluents was added. The prepared inoculum $(200 \mathrm{ml})$ was added aseptically to make up $4 \mathrm{~L}$ of working volume. The reactor was operated at room temperature and agitation speed of $300 \mathrm{rpm}$. Aeration was effected with compressed air at a flow rate of 2.0 volume of air per volume broth per minute (vvm). The fermentation was carried out for 14 days after which samples were taken for decolourization, COD and BOD analysis. All samples were filtered through Whatman paper No 1 and centrifuged for $10 \mathrm{~min}$. The pellet was discarded and clear solution was analyzed.

Determination of colour removal: Decolourization of the textile waste effluents was determined by measuring the absorbance at the pre-determined absorbance maximum $(600 \mathrm{~nm})$ using a UV-visible spectrophotometer (Labomed, USA). The decolourization efficiency was expressed as per the following equation:

$$
\% \text { Decolourization }=\left[\frac{A-B}{A}\right] \times 100
$$

Where, A and B are the initial and final absorbance, respectively.

Determination of chemical oxygen demand: COD analyses of the untreated and treated samples from bioreactor were determined by a standard colorimetric method (APHA-AWWA, 1985). Ten millilitres of the sample was poured into a $250 \mathrm{ml}$ conical flask, and $5 \mathrm{ml}$ of concentrated sulphuric acid and about $1 \mathrm{~g}$ of copper sulphate were added. Three millilitres of prepared N/40 potassium permanganate solution was then added to the contents in the flask and subsequently immersed in boiling water for 30 min. Three millilitres of prepared N/40 sodium oxalate was then added and immediately titrated with N/40 potassium permanganate until a violet colour was obtained. This procedure was repeated for the blank using ten millilitres of distilled water instead of ten millilitres of sample. 
Determination of biochemical oxygen demand: BOD analyses of the untreated and treated sample from bioreactor were performed by using 5- day BOD test. The BOD test was carried out using a BOD track instrument which is a refrigerated incubator that has chassis on which amber sample bottles are placed and the bottles are connected by caps and tubing to the instrument's pressure sensor. The waste water samples were cooled to $20^{\circ} \mathrm{C}$ by dipping the sample container in ice bucket. Using a clean measuring cylinder, $200 \mathrm{ml}$ of the sample was poured into each amber sample bottle. A magnetic stirring bar was put into each of the sample bottles as well as the content of one package of BOD Nutrient buffer solution pillow to allow for optimum bacteria growth. Stopcock grease was then applied to the sealed lips of the bottles and to the top of the sealed cups. Each seal cup was then put into the neck of the bottle. One Lithium hydroxide powder pillow was added through a polyethylene funnel into each of the seal cups. This removes the carbon-dioxide produced during the oxidation of the organic matter within the sample. The bottles were then placed on the chassis of the BOD Track. Appropriate tubes were then connected to each bottle and tightened firmly to the cap. The BOD Track was then placed in the incubator and left for 5 days. Pressure sensors monitor air pressure within the sample bottles and when the air pressure drops, the pressure changes are converted to $\mathrm{mg} / \mathrm{L}$ BOD. The BOD result was read directly from the control panel display by pressing the key corresponding to each sample bottle.

HPLC analysis of degraded products: The textile dye degradation was monitored by HPLC as the decolourization progressed. Ten millilitres of samples were taken at the start of the experiment and daily $(24 \mathrm{~h})$, centrifuged and filtered through $1.2 \mu \mathrm{m}$ filter paper. The filtrate was extracted three times with methylene chloride and evaporated in rotary evaporator with $45-50^{\circ} \mathrm{C}$ water bath, after which the residue was dissolved in $2 \mathrm{ml}$ methanol. The extracted samples were analyzed using $60 \%$ acetonitryl and $40 \%$ water (mobile phase) at a flow rate of $0.5 \mathrm{ml} / \mathrm{min}$. The elution of the samples was done isocratically using a C 18 reversed phase column (RPC - 18 phenomenex) and the UV-VIS detector was set at $285 \mathrm{~nm}$.

\section{RESULTS AND DISCUSSION}

A total of six bacterial isolates that are capable of utilizing textile dye as a source of carbon and energy were obtained from the soil contaminated with textile waste effluents. The gram staining, morphological and biochemical characterization of the isolates revealed the following bacterial species: Pseudomonas fluorescence, Pseudomonas nigificans and Pseudomonas gellucidium; and the fungal species, which are Aspergillus niger, Fusarium compacticum and Proteus morganii.

Figure 1 shows the percent dye decolourization by the different microbial isolates. It could be seen that all the isolated microorganisms has a percent dye decolourization between 39 and 48\%. Comparatively among the bacterial isolates, Pseudomonas fluorescence demonstrated a higher percent dye decolourization $(46 \%)$ than Pseudomonas nigificans (41\%) and Pseudomonas gellucidium (39\%), respectively. Also, in comparison among the fungal isolates, Aspergillus niger showed a higher percent dye decolourization (48\%) than Proteus morganii (44\%) and Fusarium compacticum (42\%), respectively. Generally, the order of percent dye decolourization among all the isolates is as follows: Aspergillus niger > Pseudomonas fluorescence > Proteus morganii > Fusarium compacticum > Pseudomonas nigificans $>$ Pseudomonas gellucidium.

The efficient use of different Aspergillus species (A. niger, A. foetidus, A. fumigates and A. terreus) for decolourization of different types of dye has been reported (Sumathi and Manju, 2000; Ali et al., 2007; Jin et al., 2007; Andleeb et al., 2010). The results of HPLC analyses (not shown) taken for the untreated and treated samples proved the role of degradation mechanisms in the dye colour removal phenomenon. It has been reported that decolourization of dye effluents is as a result of dye degradation mechanism (Glenn and Gold, 1983; Wesenberg et al., 2002; Ramya et al., 2007). 


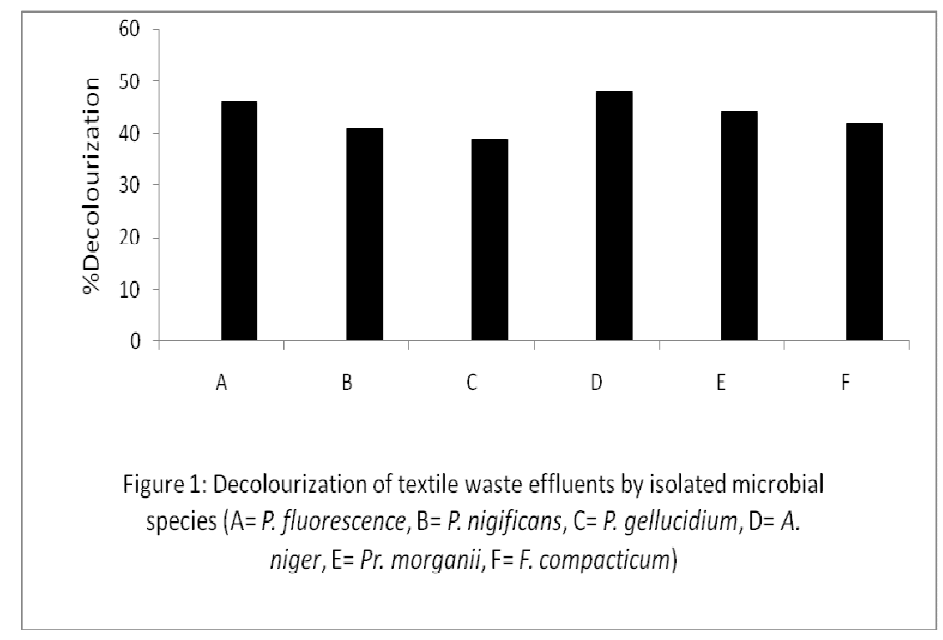

The percent COD and BOD reductions of the treated textile waste effluents by the different microbial isolates is shown in Figure 2 and Figure 3, respectively. It is seen that all the isolates demonstrated a COD reduction of between 74 and $97 \%$ and a BOD reduction of between 77 and $95 \%$, respectively. In comparison among the bacterial isolates, Pseudomonas fluorescence depicted a relatively higher COD and BOD reductions (95\% and 93\%) than Pseudomonas nigificans (88\% and $82 \%$ ) and Pseudomonas gellucidium (74\% and $77 \%$ ), respectively. Among the fungal isolates, the Aspergillus niger revealed a relatively higher \% COD and BOD reduction (97\% and 95\%) than Proteus morganii $(93.5 \%$ and $91 \%)$ and Fusarium compacticum (92\% and 88\%). Nevertheless, Aspergillus niger had relatively higher \% COD and BOD reductions than other bacterial and fungal isolates. Pourbabaee et al. (2006) and Andleeb et al. (2010) observed similar reductions in COD and BOD in their study of aerobic biotreatment of Terasil black in textile effluent by a newly isolated Bacillus sp. and sulfur black by Aspergillus terreus SA 3, respectively. High COD reduction in the treatment of textile effluent by Pseudomonas species has also been reported (Olukanni et al., 2006).

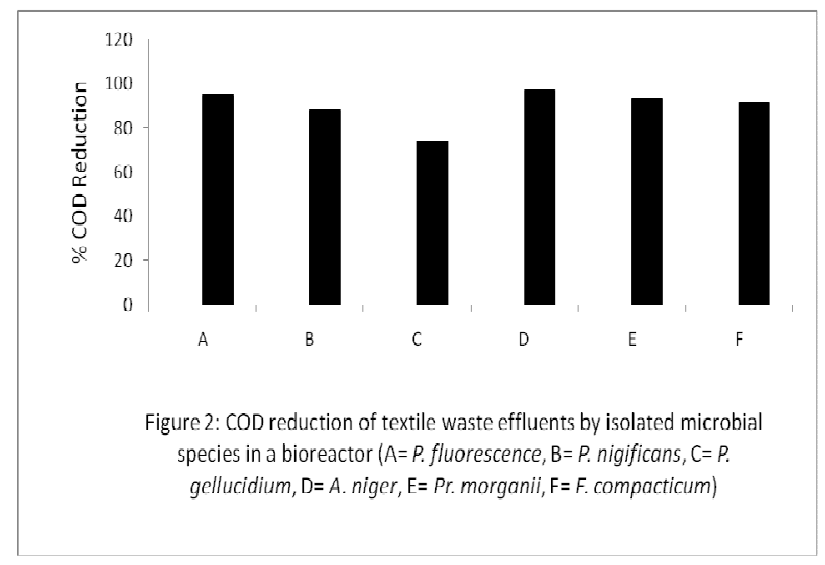




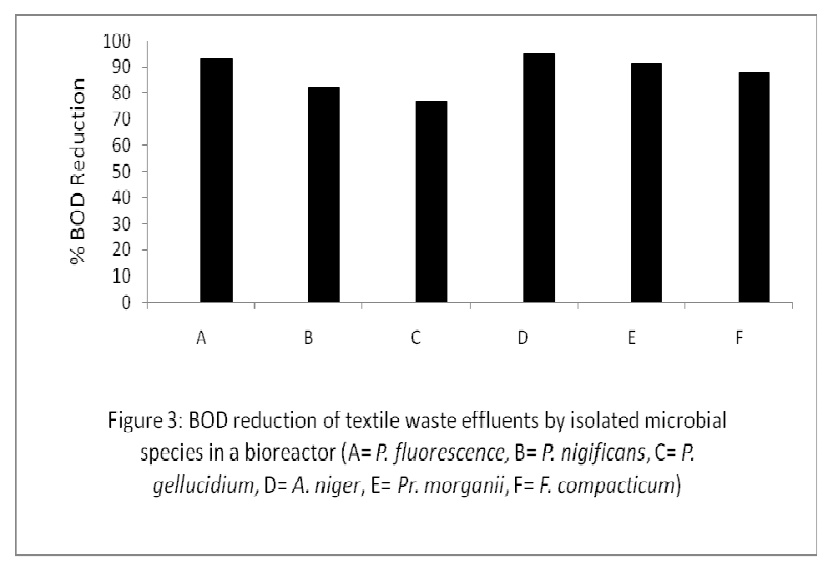

Since Pseudomonas fluorescence and Aspergillus niger relatively had a higher percent colour removal, COD and BOD reductions than other bacterial and fungal isolates respectively, they were further used as binary mixed culture to study the biodecolourization of dye in textile waste effluents under the same experimental conditions. The textile dye waste effluent with $30 \mathrm{mg} / \mathrm{L}$ dye concentration was diluted with sterile distilled water to obtain waste effluents with varying dye concentration of 10, 15, 20 and 25 $\mathrm{mg} / \mathrm{L}$, respectively. The textile waste effluents with dye concentration of 10 to $30 \mathrm{mg} / \mathrm{L}$ were introduced into the bioreactor and the percentage decolourization was monitored as shown in Figure 4. Maximum colour removal of $100 \%, 95 \%, 88 \%, 79 \%$ and $72 \%$ by the binary mixed culture of Pseudomonas fluorescence and Aspergillus niger was observed when the bioreactor was operated for 14 days for 10 , $15,20,25$ and $30 \mathrm{mg} / \mathrm{L}$ textile dye removal in the textile waste effluents (Figure 4). This indicates that the percent decolourization decreased with increased dye concentration. Thus, the rate of decolourization decreased with increased dye concentration. A similar observation has been reported for the colour removal of Reactive blue dye by Polyporus rubidus (Dayaram and Dasgupta, 2008) and the removal of sulfur black by Aspergillus terreus SA 3 (Andleeb et al., 2010), respectively. Moreover, the mixed culture had a higher percent decolourization $(72 \%)$ of textile waste effluents with $30 \mathrm{mg} / \mathrm{L}$ dye concentration than the individual isolates. The advantages of employing mixed cultures (microbial consortium) as opposed to pure cultures in bioremediation have been demonstrated (Agarry et al., 2008).

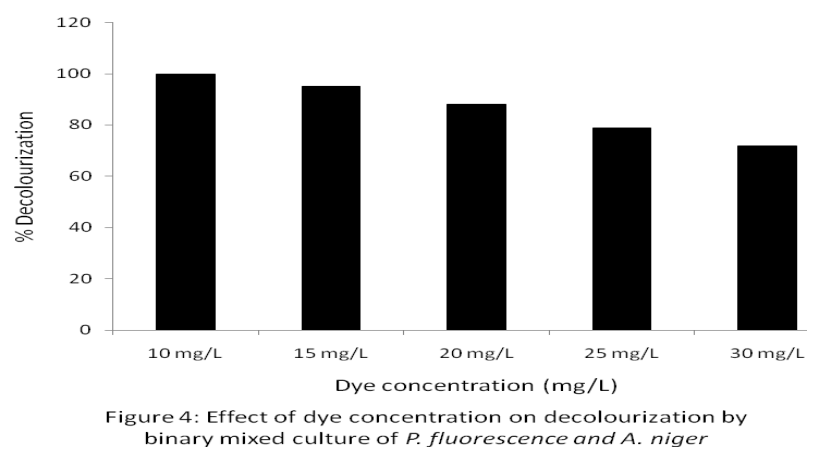

Conclusions: Several microorganisms may seem to have a potential for dye decolourization and degradation. However, it has been reported that very few strains can withstand the conditions of dyeing effluents (Maier, 2004). Thus, as a preliminary step in the development of textile waste effluents biotreatment process involving indigenous microbial species, the present study have shown that
Aspergillus niger, Pseudomonas fluorescence, Proteus morganii, Fusarium compacticum, Pseudomonas nigificans and Pseudomonas gellucidium, respectively, has a significant potential for dye decolourization and degradation. Therefore, they are promising material for the removal of dyes from textile waste effluents. The present bioreactor system due to its cost effectiveness and easy 
maintenance has great potential to be used for the biotreatment of textile dye waste effluents.

\section{REFERENCES}

Agarry, S. E.; Solomon, B. O. and Layokun, S. K. (2008). 'Kinetics of batch microbial degradation of phenols by indigenous binary mixed culture of Pseudomonas aeruginosa and Pseudomonas fluorescence'. Afri. J. Biotechnol. Vol.7 (14), pp 24172423.

Ali, N.; Hameed, A.; Ahmed, S. and Khan, A. G. (2007).' Decolorization of structurally different textile dyes by Aspergillus niger SA1'. World J. Microbiol. Biotechnol., Vol.24, pp 1067 - 1072.

Andleeb, S.; Atiq, N.; Ali, M. I.; Razi-UL-Hussain, R.; Shafique, M.; Ahmed, B.; Ghumro, P. B.; Hussain, M.; Hameed, A. and Ahmed, S. (2010). 'Biological treatment of textile effluent in stirred tank bioreactor'. Int. J. Agric. Biol., Vol.12 (2), pp $256-260$.

APHA-AWWA (1985). 'Standard methods for the examination of waste and wastewater', $16^{\text {th }} \mathrm{ed}$. American Public Health Association, Washinghton, DC.

Borchart, M. and Libra, J. A. (2001). 'Decolorization of reactive dyes by the white-rot fungus, Trametes versicolor in sequencing batch reactors'. Biotech. Bioeng., Vol.75, pp $313-321$.

Cheriaa, J.; Bettaieb, F.; Denden, I. and Bakhrouf, A. (2009). 'Characterization of new algae isolated from textile wastewater plant'. J. Food, Agric. Environ., Vol.7, pp 700 - 704.

Cooper, P. (1995). 'Colour in dye house effluent'. Society of dyers and colourists, Bradford.

Dayaram, P. and Dasgupta, D. (2008). 'Decolorisation of synthetic dyes and textile wastewater using Polyporus rubidus'. J. Environ. Biol., Vol.29 (6), pp 831 - 836.

Do, T,; Shen, J.; Cawood, G. and Jeckins, R. (2002). 'Biotreatment of textile effluents using Pseudomonas spp. Immobilized on polymer supports'. In: Advances in biotreatment for textile processing. Hardin, I. R., Akin, D.E and Wilson, J. S. (Eds). University of Georgia press.

Duran, N.; Rosa, M. A.; Annibale, A. D. and Gianfreda, L. (2002). 'Applications of laccases and tyrosinases (phenoloxidases) immobilized on different supports: A review'. Enzym. Microb. Technol., Vol.31, pp 907 - 931.

Fu, Y. and Viraraghavan, T. (2002). 'Dye biosorption sites in Aspergillus niger'. Bioresource Technol., Vol.82, pp 139 - 145.

Glenn, J. K. and Gold, M. H. (1983). 'Decolorization of several polymeric dyes by the lignin degrading basidiomycete phanerochaete chrysoporium. Appl. Environ. Microbiol., Vol.4, pp 1741 - 1747.

Gogate, P. R. and Pandit, A. B. (2004). 'A review of imperative technologies for wastewater treatment II: hybrid method'. Advan. Environ. Res. Vol.8, pp $553-597$.

Hataka, A. (1994). 'Lignin modifying enzymes from selected white-rot fungi: production and role in lignin degradation'. FEMS Microbiol. Rev., Vol.13, pp 125 - 135 .

Holt, J. G.; Krieg, N. R.; Sneath, P. H. A.; Stanley, J. T. and William, S. T. (1994). 'Bergey's Manual of Determinative Bacteriology'. Baltimore, USA, William and Wilkins.

Jin, X. C.; Liu, G. Q.; Xu, Z. H. and Tao, W. Y. (2007). 'Decolorization of a dye industry effluent by Aspergillus fumigates XC6'. Appl. Microbio. Biotechnol., Vol.74, pp 239 - 243.

Jumarkar, N.; Murty, D. S.; Bhatt, N. S. and Madamwar, D. (2006). 'Decolorization of diazo dye remazol brilliant orange 81 by a novel bacterial consortium'. World J. Microbiol. Biotechnol., Vol.22, pp 163 - 168.

Kang, S-F.; Yen, H-Y.; Liao, C-H. and Yao, Y-C. (2010). 'Decolorization and mineralization of textile effluent by $\mathrm{H}_{2} \mathrm{O}_{2}$ /ultraviolet processes'. Environ. Eng. Sci. Vol.27 (4), pp 357 - 363.

Kim, S.; Park, C.; Kim, J. H.; Lee, J. and Kim, S. W. (2003). 'COD reduction and decolorisation of textile effluents using a combined process'. $J$. Biosci. Bioeng., Vol.95, pp $102-105$.

Maier, J.; Kandelbauer, A.; Erlacher, A.; CavacoPaulo, A. and Gubits, G. M. (2004). 'A new alkali-thermostable azoreductase from Bacillus sp. strain SF'. Appl. Environ. Microbiol., Vol.70, pp $837-844$.

Maxima, C. and Costa-Ferreira, M. (2004). 'Decolourization of reactive textile dyes by Irpex 
lacteus and lignin modifying enzymes'. Proccess Biochem., Vol.39, pp 1475 - 1479.

McKay, G. (1979). 'Waste colour removal from textile effluents'. American Dyestuff. Rep., Vol.68, pp 29 - 36

McMullan, G.; Meehan, C.; Conneely, A.; Nirby, N.; Robinson, P.; Nigam, I.; Bannat, M. and Marchant, S. W. F. (2001). 'Minireview: Microbial decolorization and degradation of textile dyes'. Appl. Microbiol. Biotechnol., Vol.56, pp $81-87$.

Olukanni, O. D.; Osuntoki, A. A. and Gbenle, G. O. (2006). 'Textile effluent biodegradation potentials of textile effluent-adapted and non-adapted bacteria'. Afri. J. Biotechnol., Vol.5 (20), pp 1980 $-1984$

Pourbabaee, A. A.; Malekzadeh, F.; Sarbolonki, M. N. and Najafi, F. (2006). 'Aerobic decolorization and detoxification of a disperse dye in textile effluent by a new isolate of Bacillus sp'.

Raghukumar, G.; Chandramohan, D.; Michael, F. C. and Reddy, C. A. (1996). 'Degradation of lignin and decolorization of paper-mill bleach plant effluent (Bpe) by marine fungi'. Biotech. Lett. Vol.18, pp 105 - 106.

Ramya, M.; Anusha, B.; Kalavathy, S. and Devilaksmi, S. (2007). 'Biodecolorization and biodegradation of reactive blue by Aspergillus sp', Afri. J. Biotechnol., Vol.6 (12), pp 1441 1445 .

Revankar, M. S. and Lele, S. S. (2007). 'Synthetic dye decolorization by whiterot fungus, Ganodema sp WR- I'. Bioresource Technol., Vol.98, pp 775 -780 .

Robinson, T.; McMullan, G.; Marchant, R. and Nigam, P. (2001). 'Remediation of textile dyes in textile rffluent: A critical review on current treatment technologies with a proposed alternative'. Bioresource Technol., Vol.77, pp 247 -255 .

Singh, K. D.; Sharma, S.; Dwivedi, A.; Pandey, P.; Thakur, R. L. and Kumar, V. (2007). 'Microbial decolorization and bioremediation of melanoidin containing molasses spent wash'. J. Environ. Biol. Vol.28, pp 675 - 677.
Sumathi, S. and Manju, B. S. (2000). 'Uptake of reactive textile dyes by Aspergillus foetidus'. Enzyme Microb. Technol., Vol.27, pp 347 - 355.

Svobodova, K.; Erbanova, P.; Sklenar, J. and Novotny, C. (2006). 'The role of mn- dependent peroxidase in dye decolorization by sterile and agitated culture of Irpes lacteus'. Folia Microbiol., Vol.51, pp 573 - 578 .

Togo, C. A.; Mutambanengwe, C. C. Z. and Whitely, C. G. (2008). 'Decolourisation and degradation of textile dyes using a sulphate reducing bacteria (SRB)- biodigester microflora co-culture'. Afri. J. Biotechnol., Vol.7 (2), pp 114 - 121.

Verma, P.; Baldrian, P. and Nerud, F. (2003). 'Decolourization of structurally different synthetic dyes using cobalt (II)/ascorbic acid/hydrogen peroxide system'. Chemosphere, Vol.50, pp 975 979.

Wagner, S. (1993). 'Improvement in products and processing to diminish environmental impact'. COTTECH conference, Raleigh NC.

Wesenberg, D.; Kyriakides, I. and Agathos, S. N. (2003). 'White-rot fungi and their enzymes for the treatment of indusrial dye effluents'. Biotechnol. $A d v$., Vol.22, pp $161-187$.

Zhang, F.; Yediler, A. Liang, X. and Kettrup, A. (2004). 'Effects of dye additives on the ozonation process and oxidation by-products: a comparative study using hydrolyzed C1 Reactive red 120'. Dyes pigments, Vol.60, pp $1-7$. 